\title{
Working
}

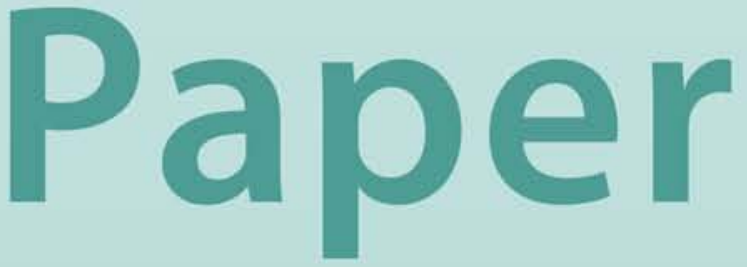


Bank Failures and Fiscal Austerity: Policy Prescriptions for a Developing Country

\author{
Andrew Feltenstein
}




\title{
IMF Working Paper
}

\author{
IMF Institute
}

\section{Bank Failures and Fiscal Austerity: Policy Prescriptions for a Developing Country ${ }^{1}$}

Prepared by Andrew Feltenstein

Authorized for distribution by Mohsin S. Khan

May 2000

\begin{abstract}
The views expressed in this Working Paper are those of the author(s) and do not necessarily represent those of the IMF or IMF policy. Working Papers describe rescarch in progress by the author(s) and are published to elicit comments and to further debate.
\end{abstract}

This work employs a dynamic general equilibrium model to evaluate the causes and implications of bank insolvencies. The model is applied to stylized data from several South Asian countries. It derives conclusions about policy instruments designed to alleviate the impact of insolvencies. Firms are subject to intertemporal solvency conditions, and the public withdraws deposits when borrowers default. If banks optimize by restricting credit to risky borrowers, these failures can be partially avoided. Numerical simulations conclude that the combination of compensating monetary policy and restrictive fiscal policy offers the best way of responding to a bank crisis caused by exogenous shocks.

JEL Classification Numbers:D58; E63; H62

Keywords: bank failures; general equilibrium

Author's E-Mail Address: afeltenstein@imf.org

\footnotetext{
${ }^{1}$ The author is a professor of economics at Virginia Polytechnic Institute. He wrote this paper while a Visiting Scholar at the IMF Institute. He would like to thank Ralph Chami and Mohsin Khan for a number of helpful comments.
} 


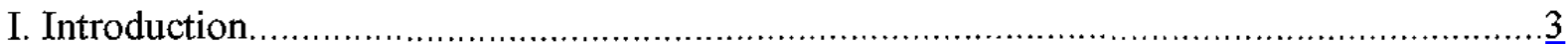

II. Applied General Equilibrium and A Stylized Banking System.....................................

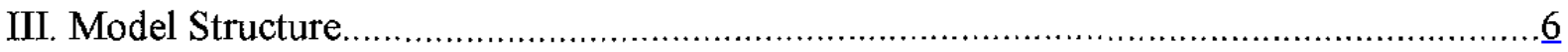

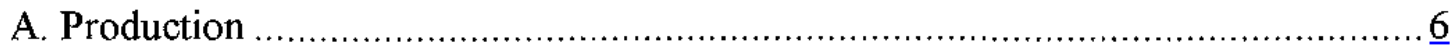

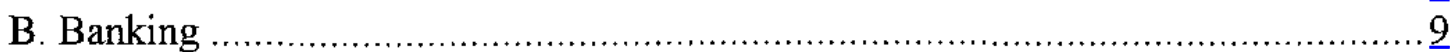

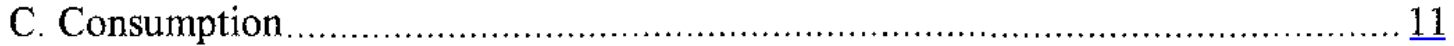

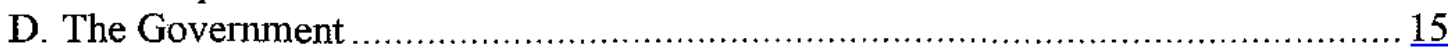

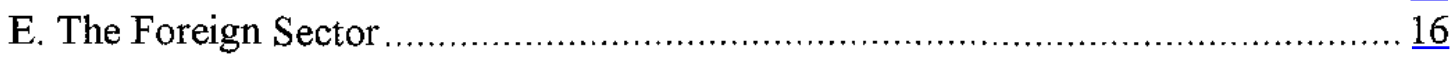

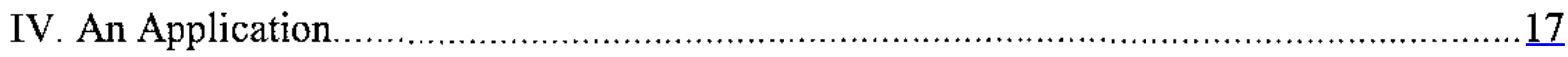

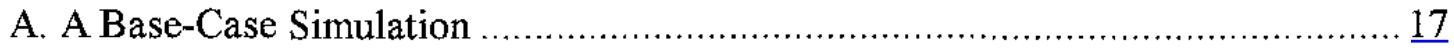

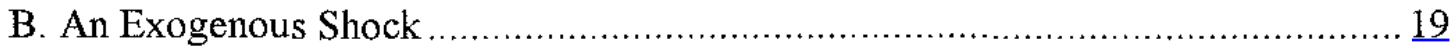

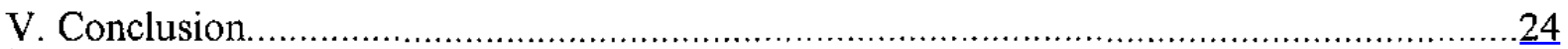

Text Tables

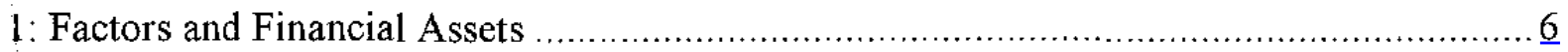

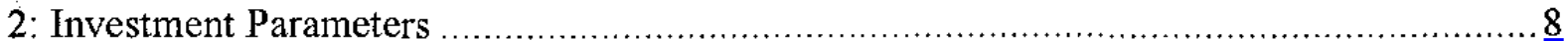

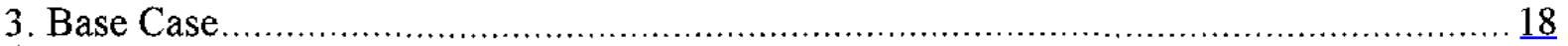

4. A Monetary Contraction.......................................................................... 20

5. A Monetary Contraction with Optimizing Bank Behavior .................................... 21

6. A Monetary Contraction with Compensating Central Bank Behavior ........................ 23

7. Monetary Contraction with Monetary Compensation and Fiscal Reduction ................... 24

Appendix

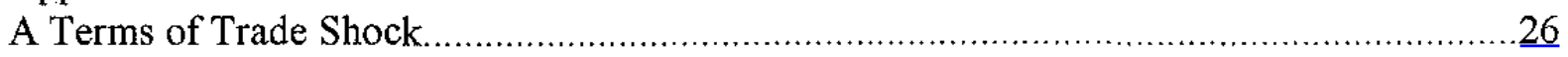

Appendix Tables

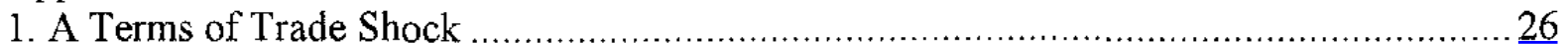

2. A Terms of Trade Shock with Monetary Compensation......................................... $\underline{27}$

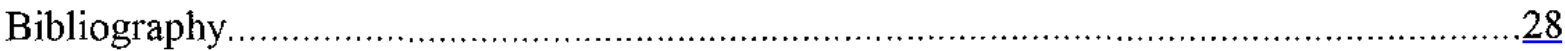




\section{INTRODUCTION}

This paper develops a model for the analysis of failures in the banking system, and compensating policy recommendations. ${ }^{1}$ This issue is becoming of increasing importance in a variety of developing countries, due to the problems for macroeconomic management which banking failures cause. Although these failures may have occurred because of mismanagement in the lending process, it is also possible that unexpected changes in the behavior of depositors could lead to runs on the banking system and a resulting collapse.

Accordingly, we will develop an intertemporal general equilibrium model that can generate endogenous bank failures, and which allows alternative policies to compensate for these failures. Among these policies are the provision of discount loans and open market injections of liquidity by the central bank to compensate for nonperforming assets, as well as the use of fiscal instruments to reduce interest rate pressures on debtors. We will develop numerical applications of our model using certain stylized data. These applications should serve to illustrate potential outcomes and uses of our model, which cannot be solved analytically. In the next section we will carry out a brief overview of our type of model, emphasizing applications to developing countries. Section III will develop the theoretical structure of our model. Section IV will discuss the parametarization of the model and will give examples of numerical simulations of the model, indicating how bank failures may be generated by exogenous shocks. The examples will also look at some policy prescriptions designed to alleviate these failures.

\section{Applied General Equilibrium and A Stylized Banking System}

Applied general equilibrium models are in wide use for the evaluation of government policies. Among the many different types of models, two general types stand out. The first of these employs large scale, highly detailed structures representing the production and consumption technologies of a particular economy. This approach generally does not incorporate financial assets, and hence lacks certain intertemporal features.

The second approach generally incorporates smaller scale models with less sectoral detail. On the other hand, the models have intertemporal structures which permit the evaluation of a wide variety of macroeconomic policies effecting growth, inflation, and investment, while still being able to examine the broad sectoral implications of these policies.

Among large-scale models applied to issues of developing countries are Benjamin and Devarajan (1985), De Melo (1988), Grais, de Melo, and Urata (1986), Kehoe and Serra-

\footnotetext{
${ }^{1}$ Blejer, Feldman, and Feltenstein (1998) develop a model of insolvencies generated by bank panics, and motivate this model by considering certain recent experiences in Latin America.
} 
Puche (1980), Kouwennar (1988), Levy (1987), Lewis and Urata (1984), Narayana, Parikh, and Srinivasan (1991), and Taylor (1990). Shoven and Whalley (1984) offers a useful, if somewhat dated, survey of the use of numerical general equilibrium models for the analysis of fiscal issues.

The model we develop has a considerable amount of sectoral detail, but its key feature will be the incorporation of financial instruments and, in particular, a banking sector. Among recent papers that consider such macroeconomic general equilibrium frameworks are Labadie (1994), which analyzes the effects of monetary policy on financial intermediation using a model with government, producer, household, and banking, similar to ours. DiazGimenez, Prescott, Fitzgerald, and Alvarez (1992) incorporate banking in a computational general equilibrium model, while Altig, Carlstrom, and Lansing (1995) use an applied general equilibrium framework, with financial assets, for both forecasting and policy advice. Chari, Christiano, and Eichenbaum (1995) develop a quantitative general equilibrium model that incorporates a banking sector and generates business cycles, and use it to analyze different types of monetary aggregates. Feltenstein (1992) constructs a simple two period model of Mexico that incorporates domestic and foreign financial assets and analyzes "Dutch disease" phenomena. A similar model is used to address quite a different issue in Feltenstein and Shah (1993), where an intertemporal model is developed to address the issue of investment tax credits.

We will introduce a very specialized version of a banking system in our model. This banking system captures certain key features of a number of other developing countries, especially those in South Asia. In particular, there is a set of banks that specializes in particular sectors of the economy, although it may also do some lending to other sectors. This arrangement does not come from any efficient economic outcome, but is based on certain economic and political realities. We will ignore the possibility of financial innovation in our model, although such innovation might well occur in reality. ${ }^{2}$

The banking system in most South Asian countries currently consists of some nationalized banks and some private banks, many of which are insolvent. There are a variety of nonoptimizing banking practices that would never survive a competitive market. In particular there are specialized banks designed to serve the agricultural, industrial, and agricultural development sectors. The origins of these specialized banks are essentially political. The recipients of these loans are generally not evaluated on risk and return criteria, but, rather, most loans are made to politically connected industrial companies, even when there is little chance of repayment. In fact, the finance ministry makes line item expenditures, which become deposits in the specialized banks. These deposits are then earmarked for loans to the targeted sectors. ${ }^{3}$

\footnotetext{
${ }^{2}$ See, for example, Merton (1995)

${ }^{3}$ This was pointed out by Mohsin Khan.
} 
This phenomenon of directed credit through specialized banks is typical of many developing countries. Bandiera, and others (1999) say,

"In developing countries, intervention in the financial sector went considerably further than the regulation of interest rates and of credit expansion... In some countries banks were required to hold as much as one-half or more of their liabilities in the form of reserve or liquid assets (often deposits at the central bank) and another large part of the portfolio was dominated by directed credit... In some cases, the small size of the economy meant that a government requirement to provide financial support for a sector such as steel-making meant in practice lending to a single steel company, with the result that the banks viewed the risk as belonging to the authorities."

We should note that Bandiera, and others (1999) are speaking about Chile, Ghana, Indonesia, Korea, Malaysia, Mexico, Turkey, and Zimbabwe, hence a group of countries quite different from those in South Asia. Nonetheless, the same type of specialized banking has been used.

A key characteristic of such specialized banking is that loans are not typically based on assessments of project profitability and the probability of repayment. Explanations for this apparently nonoptimal behavior ranges from the political power of large lenders, poor oversight on the part of bank lending officials, and the lack of legal repercussions for those who default on loans. In fact, the specialized banks act as a channel for directed loans from the finance ministry, which may be using political criteria for targeting its spending.

There are a wide variety of issues that can be addressed in the context of this type of model. In order to narrow our focus, we will analyze only three general topics. We will first see how a financial shock can generate bank insolvency, and how optimizing bank behavior can alleviate these insolvencies. ${ }^{4}$ We will then examine compensatory monetary policies that might be used to alleviate problems of bank insolvency. Finally, we will see how a fiscal reduction can be combined with a monetary expansion to relieve pressures on the banking system.

\footnotetext{
${ }^{4}$ We will introduce a type of optimizing bank behavior similar to that developed in Calomiris and Wilson (1998) in which banks attempt to keep deposits by reducing default risk on their assets.
} 


\section{MODEL STRUCTURE}

In this section we will develop the analytical structure of our model. Much of this structure is designed in order to permit a numerical implementation. Our model has $\mathrm{n}$ discrete time periods. All agents optimize in each period over a 2 period time horizon. That is, in period $\mathrm{t}$ they optimize given prices for periods $t$ and $t+1$ and expectations for prices for the future after $t+1$. When period $t+2$ arrives, agents re-optimize for period $t+2$ and $t+3$, based on new information about period $t+2$. For example, there may have been a technology shock, certain banks may have become insolvent, or the structure of demand may have changed. Thus the savings decision made in period $t+I$ may not give an optimal allocation when period $t+2$ arrives.

We thus have a system in which expectations are consistent for 2 periods and then may be inconsistent thereafter. Updating takes place and expectations are again consistent for 2 periods and inconsistent thereafter. We adapt this framework for an essentially technical reason. We wish to avoid having a perfect foresight model since it would not be possible to generate insolvencies in such a model. The alternative would, of course, be to develop a stochastic model. The additional complexity of such a model is, however, beyond the scope of our current computational framework and we therefore have chosen to avoid it.

Our model structure is related to a number of earlier papers, possibly starting with Strotz (1956). Here preferences are inconsistent over time, primarily because the future does not turn out as anticipated. Thus it may be optimal for agents to commit themselves for a few periods into the future. They may be better off, however, if they re-optimize at some later date, based on their own changed preferences or changes in economic variables. This is quite different from the notion of time inconsistency of Kydland and Prescott (1977), where rational behavior by economic agents itself leads to inconsistencies in what would otherwise be an optimal government plan.

\section{A. Production}

There are 8 factors of production and 3 types of financial assets:

Table 1: Factors and Financial Assets
1-5. Capital types
9. Foreign currency
6. Urban labor
10. Rural labor
7. Domestic currency
11. Land
8. Bank deposits 
The five types of capital correspond to five aggregate nonagricultural productive sectors. We could have any number of capital types without affecting the structure of the model, our choice of five is essentially arbitrary. ${ }^{5}$ Each of these factors and financial assets is replicated in each period and, accordingly, has a price in each period. Period 1, domestic currency, is the numeraire.

An input-output matrix, $A_{t}$, is used to determine intermediate and final production in period t. Corresponding to each sector in the input-output matrix, sector specific value added is produced using capital and urban labor for the nonagricultural sectors, and land and rural labor in agriculture. ${ }^{6}$

Assuming that there are more than five sectors in the economy, the different factors would be allocated across the economy so that agriculture uses land and rural labor, and all other sectors use one of the five capital types plus urban labor. Accordingly, capital is perfectly mobile across a given sub-sector, but is immobile across other sub-sectors. Labor, on the other hand, may migrate from the rural to the urban sector.

The specific formulation of the firm's problem is as follows. Let $y_{K i}^{j}, y_{L i}^{j}$ be the inputs of capital and urban labor to the jth nonagricultural sector in period i. Let $Y_{G i}$ be the outstanding stock of government infrastructure in period $i$. The production of value added in sector $\mathrm{j}$ in period $\mathrm{i}$ is then given by:

$$
v a_{j i}=v a_{j i}\left(y_{K i}^{j}, y_{L i}^{j}, Y_{G i}\right)
$$

where we suppose that public infrastructure may act as a productivity increment to private production.

Sector $\mathrm{j}$ pays income taxes on inputs of capital and labor, given by $t_{K i j}, t_{L i j}$, respectively, in period i. Agriculture is taxed on its use of labor. ${ }^{7}$ Hence the effective price for labor and capital paid by sector $\mathrm{j}$ is:

\footnotetext{
${ }^{5}$ We wish to avoid using a single, perfectly mobile, capital type since it would generate overly rapid sectoral adjustments.

${ }^{6}$ The use of neo-classical value added functions "sitting above" an input-output matrix is common. The reader may wish to see Shoven and Whalley (1984) for articles that use this approach.

${ }^{7}$ The interpretation of these taxes is thus as a profit tax and a personal income tax that is withheld at the source.
} 


$$
\widetilde{P}_{L i j}=\left(1+t_{L i j}\right) P_{L i}, \widetilde{P}_{K i j}=\left(1+t_{K i j}\right) P_{K i j}
$$

Thus if $\widetilde{P}_{K i j}, \widetilde{P}_{L i j}$ are the prices of capital and labor in period $\mathrm{i}$, then the prices charged by

$$
\left(P_{i}\right)=v a\left(P, Y_{G i}\right)(I+t)(I-A)^{-1}
$$

enterprises, $P_{i}$, are given by:

where $v a\left(P, Y_{G i}\right)$ is the vector of cost-minimizing value-added per unit of output.

We suppose that each type of sectoral capital is produced via a sector-specific investment technology that uses inputs of capital and labor to produce new capital. Investment is carried out by the private sector and is entirely financed by domestic borrowing. 8

The investor may receive an investment tax credit as well as a depreciation allowance. He also pays a capital, or profit tax, on the returns to his investment. Let us define the following notation.

Table 2: Investment Parameters

$$
\begin{array}{ll}
\mathrm{k}_{\mathrm{i}} & =\text { Investment tax credit in period } \mathrm{i} \text { (percent). } \\
\mathrm{d}_{\mathrm{i}} & =\text { Depreciation allowance in period } \mathrm{i} \text { (percent). } \\
\mathrm{t}_{\mathrm{ki}} & =\text { Profit (capital) tax rate (percent) } \\
\mathrm{C}_{\mathrm{Hi}} & =\text { The cost of producing the quantity } \mathrm{H}_{\mathrm{i}} \text { of capital. } \\
\mathrm{r}_{\mathrm{i}} & =\text { The interest rate in period } \mathrm{i} \\
\mathrm{p}_{\mathrm{Ki}} & =\text { The return to capital in period } \mathrm{i} . \\
\mathrm{P}_{\mathrm{Mi}} & =\text { The price of money in period } \mathrm{i} . \\
\delta & =\text { The rate of depreciation of capital. }
\end{array}
$$

\footnotetext{
${ }^{8}$ We assume that all foreign borrowing for investment is carried out by the government, so that, implicitly, the government is borrowing for the private investor but the debt thereby incurred is publicly guaranteed.
} 
Suppose, then, that the rental price of capital in period 1 , or whatever the current period might be, is $P_{1}$. If $C_{H 1}$ is the cost-minimizing cost of producing the quantity of capital, $H_{1}$, then the cost of borrowing must equal the present value of the return on new capital. Hence:

$$
C_{H 1}\left(I-k_{1}-d_{1}\right)=\sum_{i=2}^{N}\left[\frac{\left(1-t_{K i}\right) P_{K i}(1-\delta)^{i-2} H_{1}}{\prod_{j=1}^{i-1}\left(1+r_{j}\right)}\right]
$$

where $r_{j}$ is the interest rate in period $\mathrm{j}$, given by:

$$
r_{j}=I / P_{B j}
$$

where $P_{B j}$ is the price of a bond in period $\mathbf{j}$. Accordingly, the investor takes out a loan from the banking system to cover his costs. This loan then becomes an asset of the banking system.

We make one further assumption about the behavior of the individual firm. The firm, like all other agents in the model, optimizes with a 2 period time horizon for which it knows all prices. After the second period it assumes that future interest rates and returns to capital will remain the same as in period 2. ${ }^{9}$ Hence $P_{K i}=P_{K 2}, r_{i}=r_{2} ; i>2$. If at some point the present value of investment, as given in equation (3), falls below the corresponding value of debt service, then the sector is unable to pay its debt obligations which were incurred to finance this investment. Accordingly, the bank which holds these assets now holds corresponding bad debts. This situation might occur if, after the investment was incurred, the interest rate rose or the rate of return to capital fell, due to some unanticipated event. We assume that a bankrupt firm cannot invest.

\section{B. Banking}

The banking sector in our model is quite simple and is meant to capture some of the key features and problems in many developing countries. We will suppose that there is one bank for each nonagricultural sector of the economy. There are 5 such sectors, and hence 5 banks. We make this assumption of sectoral specialization of the banking system for several reasons. First, as discussed in section II, such specialization reflects the reality of countries of South Asia, as well as many other developing countries. Second, if we had only a single bank, then we would not be able to generate the type of heterogeneous failures that are

\footnotetext{
${ }^{9}$ We could have other types of expectational mechanisms, such as one in which the firm uses the trends of past prices to predict those for the future after period 2 .
} 
typical of bank panics. Third, our use of multiple banks permits us to capture the notion of more and less successful banks without introducing elements of risk or private information, which we do not have in our model.

Each bank lends primarily to the sector with which it is associated. The banks are, however, not fully specialized in the sector they correspond to. We will make the simplifying assumption that each bank hold 50 percent of the outstanding debt of its particular sector. It then holds 12.5 percent of the debt of each of the remaining four sectors. Hence bank 3 , for example, holds 50 percent of the debt of sector 3 , and 12.5 percent of sectors $1,2,4$, and 5 . Similarly, it makes 50 percent of the loans to sector 3 and 12.5 percent of the loans to the other four sectors. ${ }^{10}$ We make this assumption of diversification of assets in order to avoid a possible situation in which the insolvency of a particular sector leads to the automatic insolvency of its related bank.

We will suppose that banks follow a strategy of lending that looks at the risks associated with their borrowers. That is, as their borrowers become more insolvent, the banks ration credit to those borrowers. ${ }^{11}$ We will choose a simple functional form that connects credit rationing to borrower insolvency. Suppose that $C_{H i j}$ is the demand for borrowing by sector $\mathrm{j}$ in period $\mathrm{i}$. Suppose also that bank $\mathrm{k}$ has $D e f_{i k}$ percent of its total assets in default in period i. Let $\delta_{k}$ be a parameter specific to bank k, and let $\beta_{j k}$ be the share of borrowing by sector $\mathrm{j}$ taken by bank $\mathrm{k}$. Sector $\mathrm{j}$ then receives loans $L_{j i}$ where:

$$
L_{j i}=\sum_{k=l}^{5} \beta_{j k}\left(I-\delta_{k} D e f_{i k}\right) C_{H i j}
$$

Thus if there are no bank assets in default, then no credit rationing takes place. If assets are in default, then the credit demanded by sector $\mathrm{j}$ for investment is reduced by each bank proportionally to the share of that bank's defaulted assets in total assets. ${ }^{12}$ The

${ }^{10}$ Clearly these percentages are arbitrary and should serve only for illustrative purposes. We could have any initial pattern of distribution of bank assets across the different sectors.

${ }^{11}$ The rationale for this approach is that banks are aware that depositors will withdraw their deposits if they believe bank assets are risky. In order to reduce these withdrawals the banks, in turn, ration credit to risky borrowers. Our approach is thus a simple version of that presented in Calomiris and Wilson (1998).

${ }^{12}$ We are thus abstracting from any uncertainty across firms, as well as any notion of private information about those firms. The only information banks possess about firms is their stock of defaulted assets. 
parameter $\delta_{k}$ is bank specific and is some measure of the risk aversion of the particular bank. Higher values of $\delta_{k}$ indicate a more rapid contraction of credit in response to bad loans. Our numerical simulations will show that this admittedly ad hoc formulation of optimizing behavior by banks leads, in fact, to reductions in failures of those banks.

We impose a solvency requirement on the banking system. Namely, if $\alpha$ percent of a bank's assets are in default, caused by a corresponding insolvency in its borrowers, then the bank is declared insolvent. At this point a fraction of the bank's deposits are seized by the government. ${ }^{13}$ In particular, depositors in the bank find part of their deposits frozen. We use a simple rule to determine the fraction of a bank's deposits that is seized. If $D e f_{i k}$ is the share of bank's assets that are in default in period $\mathrm{i}$, as before, then regulators seize $\omega_{k} D e f_{i k}$ of the bank's deposits, where $\omega_{k}$ is a bank specific parameter. This seizure of deposits correspondingly reduces the bank's ability to lend.

Thus the bank's supply of loans, and hence its assets, is determined by the demand for loans from the productive sectors of the economy, as well as the risk imputed to potential borrowers. Of course its supply of loans is also restricted by the bank's existing capital. The demand for loans is, in turn, determined by the investment equations described in the previous section. The bank's deposits, and hence liabilities, are determined by the consumers' savings behavior.

\section{Consumption}

There are two types of consumers, representing rural and urban labor. We suppose that the two consumer classes have differing Cobb-Douglas demands. The consumers also differ in their initial allocations of factors and financial assets.

The consumers maximize intertemporal utility functions, which have as arguments the levels of consumption and leisure in each of the two periods. We permit rural-urban migration which depends upon the relative rural and urban wage rate. The consumers maximize these utility functions subject to intertemporal budget constraints. The consumer saves by holding money, domestic bank deposits, and foreign currency. He requires money for transactions purposes, but his demand for money is sensitive to changes in the inflation rate. In addition, the consumer's demand for bank deposits is sensitive to his perception of

${ }^{13}$ This figure of $\alpha$ percent is simply taken to correspond to standard bank regulations. That is, if the average ratio of capital to total assets in the banking system is approximately $\alpha$ percent, then an $\alpha$ percent loss of assets would be tantamount to a total liquidation of capital. In practice, a figure of 8 percent is generally used by regulators in the United States. 
the solvency of the banking system. In particular, as banks increasingly incur bad loans, the consumer's interest elasticity of money declines, causing him to reduce his bank deposits. ${ }^{14}$

Here, and in what follows, we will use $\mathrm{x}$ to denote a demand variable and $\mathrm{y}$ to denote a supply variable. In order to avoid unreadable subscripts, let us let 1 refer to period $\mathrm{i}$ and 2 refer to period $i+1$. The consumer's maximization problem is thus:

$$
\max U(x), x=\left(x_{1}, x_{L u l}, x_{L r 1}, x_{2}, x_{L u 2}, x_{L r 2}\right)
$$

such that:

$$
\left(1+t_{i}\right) P_{i} x_{i}+P_{L u i} x_{L u i}+P_{L i} x_{L r i}+P_{M i} x_{m i}+P_{B i} x_{B i}+e_{i} P_{B f i} x_{B F i}=C_{i}
$$

$P_{K l} K_{0}+P_{A l} A_{0}+P_{L u l} L_{u I}+P_{L r I} L_{r l}+P_{M l} M_{0}+r_{0} B_{0}+P_{B I} B_{0}+e_{l} P_{B F I} B_{F O}+T R_{l}=N_{I}$

$P_{K 2}(I-\delta) K_{0}+P_{A 2} A_{0} \div P_{L u 2} L_{u 2}+P_{L r 2} L_{r 2}+P_{M 2} x_{M 1}+r_{1} x_{B 1}+P_{B 2} x_{B 1}+e_{2} P_{B F 2} x_{B F 1}+T R_{2}=N_{2}$

$$
C_{i}-N_{i}
$$

${ }^{14}$ This reflects the notion that the consumer worries about the safety of his own deposits as he sees the banks become progressively more insolvent. 
$\log P_{B i} x_{B i}-\log e_{i} P_{B F i}=\alpha+\beta\left(\log r_{i}-\log \frac{e_{i+1}}{e_{i}} r_{F i}\right)$

$\log \left(L_{u i} / L_{u i}\right)=a_{1}+a_{2} \log \frac{P_{L u i}-P_{L n}}{P_{L u i}+P_{L n i}}$

$\log P_{M i} x_{M i}=a+b \log \left(1+t_{i}\right) P_{i} x_{i}-c \log \pi_{i} ; c=c(D E F / A S S E T T)$

if $P_{\text {Lui }} \geq P_{L r i} ;$ otherwise $\log \left(L_{u i} / L_{r i}\right)=0$

(if the representative household is rural, otherwise labor holdings are constant)

$$
P_{B 2} x_{B 2}=d_{o}+d_{1}\left(1+t_{2}\right) P_{2} x_{2}+d_{2}\left\lfloor\frac{r_{2}-\pi_{2}}{1+\pi_{2}}\right\rfloor
$$

where:

$\mathrm{P}_{\mathrm{i}}=$ price vector of consumption goods in period $\mathrm{i}$.

$\mathrm{x}_{\mathrm{i}}=$ vector of consumption in period $\mathrm{i}$.

$\mathrm{C}_{\mathrm{i}}=$ value of aggregate consumption in period $\mathrm{i}$ (including purchases of financial assets).

$\mathrm{N}_{\mathrm{i}}=$ aggregate income in period $\mathrm{i}$ (including potential income from the sale of real and financial assets).

$t_{i}=$ vector of sales tax rates in period $\mathrm{i}$

$P_{\text {Lui }}=$ price of urban labor in period $\mathrm{i}$.

$\mathrm{L}_{\mathrm{ui}}=$ allocation of total labor to urban labor in period $\mathrm{i}$.

$\mathrm{x}_{\mathrm{Lui}}=$ demand for urban leisure in period $\mathrm{i}$. 
$\mathrm{P}_{\text {Lri }}=$ price of rural labor in period $\mathrm{i}$.

$\mathrm{L}_{\mathrm{ri}}=$ allocation of total labor to rural labor in period $\mathrm{i}$.

$\mathrm{x}_{\mathrm{Lri}}=$ demand for rural leisure in period $\mathrm{i}$.

$a_{2}=$ elasticity of rural/urban migration.

$\mathbf{P}_{\mathrm{Ki}}=$ price of capital in period $\mathrm{i}$.

$\mathbf{K}_{0}=$ initial holding of capital.

$\mathrm{P}_{\mathrm{Ai}}=$ price of land in period $\mathrm{i}$.

$\mathrm{A}_{0}=$ initial holding of land.

$\delta=$ rate of depreciation of capital

$\mathrm{P}_{\mathrm{Mi}}=$ price of money in period $\mathrm{i}$. Money in period 1 is the numeraire and hence has a price of 1.

$\mathrm{x}_{\mathrm{Mi}}=$ holdings of money in period $\mathrm{i}$.

$\mathrm{P}_{\mathrm{Bi}}=$ discount price of a certificate of deposit in period $\mathrm{i}$.

$\pi_{\mathrm{i}}=$ domestic rate of inflation in period $\mathrm{i}$.

$r_{i}, r_{F i}=$ the domestic and foreign interest rates in period $\mathrm{i}$.

$\mathrm{X}_{\mathrm{Bi}}=$ quantity of bank deposits, that is, CD's in period $\mathrm{i}$.

$e_{i}=$ the exchange rate in terms of units of domestic currency per unit of foreign currency in period i.

$\mathrm{x}_{\mathrm{BFi}}=$ quantity of foreign currency held in period $\mathrm{i}$.

$\mathrm{TR}_{\mathrm{i}}=$ transfer payments from the government in period $\mathrm{i}$

$\mathrm{a}, \mathrm{b}, \alpha, \beta=$ estimated constants.

$d_{i}=0$ constants estimated from model simulations.

$\mathrm{DEF}=$ The value of non-performing assets in the banking system . 
ASSET $=$ Total assets of the banking system.

$c=a$ functional form that depends negatively upon the ratio of nonperforming assets to total assets in the banking system.

The left hand side of equation (5a) represents the value of consumption of goods and leisure, as well as of financial assets. The next two equations contain the value of the consumer's holdings of capital and labor, as well as the principal and interest that he receives from the domestic and foreign financial assets that he held at the end of the previous period. The equation $C_{i}=N_{i}$ then imposes a budget constraint in each period. Equation (5d) is a standard money demand equation in which the demand for cash balances depends upon the domestic rate of inflation and the value of intended consumption. There is, however, one modification. The inflation elasticity, $\mathrm{c}$, depends upon the share of nonperforming bank assets in total assets. If there are no bad assets, then $c$ takes its estimated value. As nonperforming assets rise, $\mathrm{c}$ declines.

Equation (5b) says that the proportion of savings made up of domestic and foreign interest bearing assets depends upon relative domestic and foreign interest rates, deflated by the change in the exchange rate. Finally, equation (5c) is a migration equation that says that the change in the consumer's relative holdings of urban and rural labor depends on the relative wage rates.

In period 2 we impose a savings rate based on adoptive expectations, as in equation (5e). The constants $\left(d_{i}\right)$ are estimated by a simple regression analysis, based on the previous periods. Thus if we are in period $t$, where $t$ is the end of a two-period segment, then the closure savings rate for period $t$ is determined by nominal income and the real interest rate. The constants are updated after each two-period segment by running a regression on the previous $t-2$ periods. Thus savings rates are endogenously determined by intertemporal maximization in period $t 0$, but are determined by adoptive expectations in period $t+1 .{ }^{15}$

When period $t+2$ begins, the consumer's holdings of financial assets may be different than those incorporated in the above problem, since defaults may have occurred The consumer then optimizes again for periods $t+2, t+3$, based on his new, unexpected holdings of financial assets at the beginning of period $t+2$.

\section{The Government}

The government collects personal income, corporate profit, and value-added taxes, as well as import duties. It pays for the production of public goods, as well as for subsidies. In

\footnotetext{
${ }^{15}$ Since the only information the consumer has about the future is the real interest rate, adoptive expectations are, in this case, equivalent to rational expectations.
} 
addition, the government must cover both domestic and foreign interest obligations on public debt. The deficit of the central government in period $1, D_{1}$, is then given by: ${ }^{16}$

$$
D_{1}=G_{l}+S_{l}+r_{I} B_{0}+r_{F l} e_{l} B_{F O}-T_{1}
$$

where $S_{1}$ represents subsidies given in period $1, G_{1}$ is spending on goods and services, while the next two terms reflect domestic and foreign interest obligations of the government, based on its initial stocks of debt. $\mathrm{T}_{1}$ represents tax revenues.

The resulting deficit is financed by a combination of monetary expansion, as well as domestic and foreign borrowing. If $\Delta \mathrm{y}_{\mathrm{BG}}$ represents the face value of domestic bonds sold by the government in period 1 , and $\mathrm{C}_{\mathrm{F} 1}$ represents the dollar value of its foreign borrowing, then its budget deficit in period 2 is given by:

$$
D_{2}=G_{2}+S_{2}+r_{2}\left(\Delta y_{B G 1}+B_{0}\right)+e_{2} r_{F 2}\left(C_{F 1}+B_{F 0}\right)-T_{2}
$$

where $r_{2}\left(\Delta y_{B G 1}+B_{0}\right)$ represents the interest obligations on its initial domestic debt plus borrowing from period 1 , and $\mathrm{e}_{2} \mathrm{r}_{\mathrm{F} 2}\left(\mathrm{C}_{\mathrm{F} 1}+\mathrm{B}_{0}\right)$ is the interest payment on the initial stock of foreign debt plus period 1 foreign borrowing.

The government finances its budget deficit by a combination of monetization, domestic borrowing, and foreign borrowing. We assume that foreign borrowing in period $i$, $\mathrm{C}_{\mathrm{Fi}}$, is exogenously determined by the lender. The government then determines the face value of its bond sales in period $\mathrm{i}, \Delta \mathrm{y}_{\mathrm{BGi}}$, and finances the remainder of the budget deficit by monetization. Hence:

$$
\mathrm{D}_{\mathrm{i}}=\mathrm{P}_{\mathrm{Bi}} \Delta \mathrm{y}_{\mathrm{BGi}}+\mathrm{P}_{\mathrm{Mi}} \Delta \mathrm{y}_{\mathrm{Mi}}+\mathrm{e}_{\mathrm{i}} \mathrm{C}_{\mathrm{Fi}}
$$

\section{E. The Foreign Sector}

The foreign sector is represented by a simple export equation in which aggregate demand for exports is determined by domestic and foreign price indices, as well as world income. The specific form of the export equation is:

$$
\Delta X_{n o}=\sigma_{1}\left[\frac{\pi_{1}}{\Delta e_{i}+\pi_{F i}}\right]+\sigma_{2} \Delta y_{w i}
$$

${ }^{16}$ As before, 1 denotes $\mathrm{i}$ and 2 denotes period $\mathrm{i}+1$. 
where the left hand side of the equation represents the change in the dollar value of exports in period $\mathrm{i}, \pi_{\mathrm{i}}$ is inflation in the domestic price index, ${ }^{* * *} \mathrm{e}_{\mathrm{i}}$ is the percentage change in the exchange rate, and $\pi_{\mathrm{Fi}}$ is the foreign rate of inflation. Also, ${ }^{* *} \mathrm{y}_{\mathrm{wi}}$ represents the percentage change in world income, denominated in dollars. Finally, $\sigma_{1}$ and $\sigma_{2}$ are corresponding elasticities.

The combination of the export equation and domestic supply responses then determines aggregate exports. Demand for imports is endogenous and is derived from the domestic consumers' maximization problems. Foreign lending has not been modeled, but has been taken to be exogenous. Thus gross capital inflows are exogenous, but the overall change in reserves is endogenous. Finally, we will suppose that the exchange rate is fixed. by:

The supply of foreign reserves $\mathrm{yFGi}_{\mathrm{F}}$, available to the government in period $\mathrm{i}$ is given

$$
\mathrm{y}_{\mathrm{FGi}}=\mathrm{yrG(i-1)}_{\mathrm{F}}+\mathrm{X}_{\mathrm{i}}-\mathrm{M}_{\mathrm{i}}+\mathrm{X}_{\mathrm{F}(\mathrm{i}-1)}-\mathrm{X}_{\mathrm{Fi}}+\mathrm{C}_{\mathrm{Fi}}
$$

Here $\mathrm{x}_{\mathrm{Fi}}$ represents the demand for foreign assets by citizens of the home country, so $\mathrm{x}_{\mathrm{F}(\mathrm{i}-1)}$ $\mathrm{x}_{\mathrm{Fi}}$ represents private capital flows. $\mathrm{C}_{\mathrm{Fi}}$ represents exogenous foreign borrowing by the home government.

Finally changes in the money supply in period $\mathrm{i}, \Delta \mathrm{M}_{\mathrm{Si}}$, are now given by:

$$
\Delta M_{S i}=\Delta y_{M i}+\Delta O M O_{i}+e_{i} y_{F G i}-e_{i-l} y_{F G(i-1)}
$$

where $\triangle \mathrm{y}_{\mathrm{Mi}}$ is determined by the government's financing its budget deficit, and $\triangle O M O_{i}$ represents money created via open market operations. The remainder of the right hand side represents the domestic currency value of the balance of payments.

\section{AN APPLiCATION}

In order to simulate our model we have used a variety of data sources and parameter estimates. Much of the data is derived from Ball and Feltenstein (1998). In order to implement the model, we incorporate a number of stylized parameters from several South Asian countries. Thus we would not wish to claim that our results have more than a tenuous relationship to any specific country.

\section{A. A Base-Case Simulation}

In order to use our model for counter-factual simulations, we first generate an equilibrium using benchmark policy parameters. Accordingly, we have incorporated various estimated parameters described in Ball and Feltenstein (1998). We then run the macroeconomic model for eight years. 
We take tax rates to have their estimated effective values. Government current and capital expenditures are given their historical values for the first four years, and are assumed to be maintained at the same real level for subsequent years. We also suppose that the Central Bank maintains a fixed exchange rate, with the rate being fixed at the level of the first year.

We will suppose that a sector is unable to repay its debt, as in Section III. 1, when the present value of the future stream of earnings from the investment becomes less than the corresponding debt obligations. Finally, we will suppose that the bank solvency requirement, $\alpha$ as in Section III.2, is 8 percent. Thus if a bank's nonperforming assets are greater than 8 percent of its total assets, then a portion of the bank's deposits are seized and depositors are unable to retrieve that share of their assets.

As in Section III.2, if the bank's borrowers default on their loans, then the bank loses $\omega_{K} D E F_{K i}$ of its deposits, resulting in a wealth shock to depositors. In order to be specific, we will let $\omega_{K}=1$ for all banks. Finally, for this benchmark simulation we will assume that banks do not optimize. That is, they do not ration credit when their borrowers begin to default. We will change this assumption later. Table 3 reports the simulation outcomes for the main macroeconomic variables.

Table 3. Base Case

\begin{tabular}{|c|c|c|c|c|c|c|c|c|c|}
\hline \multicolumn{2}{|l|}{ Period } & 1 & 2 & 3 & 4 & 5 & 6 & 7 & 8 \\
\hline \multicolumn{2}{|c|}{ Nominal GDP $1 /$} & 100.0 & 110.3 & 137.8 & 160.5 & 179.8 & 209.3 & 225.8 & 262.8 \\
\hline \multicolumn{2}{|c|}{ Real GDP 1/ } & 100.0 & 106.1 & 110.6 & 113.0 & 118.1 & 117.8 & 123.4 & 122.0 \\
\hline \multicolumn{2}{|c|}{ Price Level } & 100.0 & 104.0 & 124.6 & 142.0 & 152.3 & 177.6 & 183.0 & 215.4 \\
\hline \multicolumn{2}{|c|}{ Interest Rate } & 1.8 & 3.2 & 7.8 & 10.1 & 8.6 & 7.3 & 7.8 & 8.9 \\
\hline \multicolumn{2}{|c|}{ Budget deficit 2/ } & 5.9 & 5.8 & 10.3 & 9.6 & 11.8 & 11.0 & 9.8 & 8.9 \\
\hline \multicolumn{2}{|c|}{ Trade balance $2 /$} & -7.7 & -7.0 & -9.7 & -9.4 & -10.4 & -10.0 & -10.9 & -10.5 \\
\hline \multicolumn{2}{|c|}{$\begin{array}{l}\text { Net capital stock at } \\
\text { end of period } 83 /\end{array}$} & & \multicolumn{4}{|c|}{$\begin{array}{l}\text { Percent of bank assets in } \\
\text { default at end of period: }\end{array}$} & \multicolumn{3}{|c|}{$\begin{array}{l}\text { Percent of deposits } \\
\text { seized by regulators: }\end{array}$} \\
\hline & & & Period & 4 & 6 & 8 & 4 & 6 & 8 \\
\hline Sector 1 & 100.0 & & Bank 1 & 0.0 & 0.7 & 0.7 & 0.0 & 0.0 & 0.0 \\
\hline Sector 2 & 100.0 & & Bank 2 & 0.0 & 4.7 & 4.7 & 0.0 & 0.0 & 0.0 \\
\hline Sector 3 & 100.0 & & Bank 3 & 0.0 & 1.1 & 1.1 & 0.0 & 0.0 & 0.0 \\
\hline Sector 4 & 100.0 & & Bank 4 & 0.0 & 0.6 & 0.6 & 0.0 & 0.0 & 0.0 \\
\hline Sector 5 & 100.0 & & Bank 5 & 0.0 & 0.6 & 0.6 & 0.0 & 0.0 & 0.0 \\
\hline
\end{tabular}

1/ All indices are normalized for this base simulation.

2/ As a percentage of GDP.

3 / Capital stocks are nonmalized to levels of the benchmark case of Table 3. 
It may be worth making a few remarks concerning the simulated values. We would not wish to make comparisons with actual historical data from any specific country, given the illustrative nature of this example. First, notice that our model generates moderate rates of growth in real GDP for the first seven periods, after which real growth stagnates. This is primarily the result of the fixed nominal exchange rate, which becomes progressively overvalued. The budget deficit rises and then stabilizes, as the overvalued exchange rate lowers the cost of servicing foreign debt. Similarly, interest rates rise and then stabilize.

As a result of the rising interest rates, by period 6 the value of debt obligations of sector 2 are greater than the present value of the future stream of earnings of the sector on its investments. As a result, sector 2 can no longer pay its debts, and the resulting nonperforming loans are spread across the banking system. Because sector 2 is small relative to the economy, the nonperforming assets of each of the five banks remain below the 8 percent threshold at which a bank's deposits are partially seized by regulators.

\section{B. An Exogenous Shock}

Suppose now that the economy experiences a shock. As an illustrative example, we will assume that there is an unanticipated monetary contraction. Such an event might occur if, for example, the Central Bank carried out an open market sale of debt to the private banking system in order to defend the country's currency. We will impose such an open market operation, so that the monetary base is reduced. In order to be specific, we will suppose that there is an open market contraction that reduces the monetary base by 25 percent. The contraction takes place over periods 5 and 6 , so that it was not anticipated during the first four periods of the model. ${ }^{17}$ Accordingly, the optimization strategies followed by all agents for the first half of the simulation now will be found to be sub-optimal in period 5. All exogenous parameters, other than those having to do with the open market operation, remain the same as in the previous exercise. We continue to assume that there is no optimizing behavior by banks. Table 4 gives the results of this exercise.

We observe a number of changes, compared with the base case of Table 3 . In particular, the monetary contraction has brought about a significant deflation in the last two periods. There is also a resulting increase in both the real and nominal interest rates. This, in turn, leads to a general decline in the rate of capital formation in all sectors of the economy. Accordingly, there is a significant decline in real GDP and the budget deficit has risen. At the same time, the unexpected increase in interest rates has caused sector 4 , as well as sector 2 to be unable to pay its debts after period 6 . Since sector 4 is large, and its debt is spread across the entire banking system, all banks are now insolvent. That is, their ratios of nonperforming assets to total assets is above 8 percent, the level at which a bank has part of its deposits frozen. In fact, the nonrepayment of loans begins in period 5, although not shown in the

${ }^{17}$ We introduce the shock after the first four periods in order to be able to estimate the closure parameters of eq. (5). 
table. Accordingly, the consumers' elasticity of demand for money begins to decline then, as specified in equation (5d). This leads to an accelerating run on the banking system as consumers withdraw their interest bearing deposits in exchange for money, putting further pressure on interest rates and leading to the collapse in periods 6-8.

Table 4. A Monetary Contraction

\begin{tabular}{|c|c|c|c|c|c|c|c|c|c|}
\hline \multicolumn{2}{|l|}{ Period } & 1 & 2 & 3 & 4 & 5 & 6 & 7 & 8 \\
\hline \multicolumn{2}{|c|}{ Nominal GDP $1 /$} & 100.0 & 110.3 & 137.8 & 160.5 & 175.7 & 199.7 & 141.2 & 202.9 \\
\hline \multicolumn{2}{|c|}{ Real GDP 1/ } & 100.0 & 106.1 & 110.6 & 113.0 & 117.8 & 117.1 & 115.3 & 116.3 \\
\hline \multicolumn{2}{|c|}{ Price Level } & 100.0 & 104.0 & 124.6 & 142.0 & 149.1 & 170.6 & 122.5 & 174.4 \\
\hline \multicolumn{2}{|c|}{ Interest Rate } & 1.8 & 3.2 & 7.8 & 10.1 & 17.7 & 43.6 & 61.2 & 51.1 \\
\hline \multicolumn{2}{|c|}{ Budget deficit 2/ } & 5.9 & 5.8 & 10.3 & 9.6 & 12.4 & 12.1 & 44.2 & 33.5 \\
\hline \multicolumn{2}{|c|}{ Trade balance $2 /$} & -7.7 & -7.0 & -9.7 & -9.4 & -10.7 & -10.3 & -7.3 & -10.2 \\
\hline \multicolumn{2}{|c|}{$\begin{array}{l}\text { Net capital stock at } \\
\text { end of period } 83 /\end{array}$} & & \multicolumn{4}{|c|}{$\begin{array}{l}\text { Percent of bank assets in } \\
\text { default at end of period: }\end{array}$} & \multicolumn{3}{|c|}{$\begin{array}{l}\text { Percent of deposits } \\
\text { seized by regulators: }\end{array}$} \\
\hline & & & $\overline{\text { Period }}$ & 4 & 6 & $\overline{8}$ & 4 & 6 & 8 \\
\hline Sector 1 & 95.2 & & Bank 1 & 0.0 & 19.9 & 20.7 & 0.0 & 11.9 & 12.7 \\
\hline Sector 2 & 97.1 & & Bank 2 & 0.0 & 35.9 & 37.5 & 0.0 & 27.9 & 29.5 \\
\hline Sector 3 & 94.9 & & Bank 3 & 0.0 & 29.8 & 31.6 & 0.0 & 21.8 & 23.6 \\
\hline Sector 4 & 89.0 & & Bank 4 & 0.0 & 66.1 & 67.7 & 0.0 & 58.1 & 59.7 \\
\hline Sector 5 & 93.9 & & Bank 5 & 0.0 & 15.2 & 16.3 & 0.0 & 7.3 & 8.3 \\
\hline
\end{tabular}

1/ All indices are normalized with respect to the base simulation.

2/ As a percentage of GDP.

3/ Capital stocks are normalized to levels of the benchmark case of Table 3.

We thus see how a shock to a monetary aggregate can bring about bank failures. Recall that we have assumed that the banks do not optimize. That is, the banks passively lend to borrowers with out regard to the borrower's solvency. We will now impose the optimizing bank behavior described in III.2. That is, as borrowers start to fail to repay loans, banks ration credit as in equation (4). We will assume that the parameter $\delta_{k}=1$ for all banks. Table 5 gives the result of imposing the monetary contraction, but now with the assumption of optimizing bank behavior.

We observe that imposing optimizing bank behavior has had a positive impact upon the banking system. In particular, after the failures in periods 5 and 6 the banks have 
curtailed lending in periods 7 and $8 .^{18}$ The rate of return on capital rises, and the solvency of firms 2, 4 improves, and firm 4 is now able to repay its debts, with only firm 2 still being insolvent. By period 8, no bank has nonperforming assets greater than 8 percent of its total assets. As a result, no deposits are seized. On the other hand, rationing credit has caused real GDP to decline by 1.3 percent by period 8 , and capital formation has slowed.

Table 5. A Monetary Contraction with Optimizing Bank Behavior

\begin{tabular}{|c|c|c|c|c|c|c|c|c|c|}
\hline \multicolumn{2}{|l|}{ Period } & 1 & 2 & 3 & 4 & 5 & 6 & 7 & 8 \\
\hline \multicolumn{2}{|c|}{ Nominal GDP 1/ } & 100.0 & 110.3 & 137.8 & 160.5 & 175.7 & 199.7 & 143.2 & 206.1 \\
\hline \multicolumn{2}{|c|}{ Real GDP 1/ } & 100.0 & 106.1 & 110.6 & 113.0 & 117.8 & 117.1 & 113.2 & 114.8 \\
\hline \multicolumn{2}{|c|}{ Price Level } & 100.0 & 104.0 & 124.6 & 142.0 & 149.1 & 170.6 & 126.5 & 179.5 \\
\hline \multicolumn{2}{|c|}{ Interest Rate } & 1.8 & 3.2 & 7.8 & 10.1 & 17.7 & 43.6 & 62.7 & 53.2 \\
\hline \multicolumn{2}{|c|}{ Budget deficit 2/ } & 5.9 & 5.8 & 10.3 & 9.6 & 12.4 & 12.1 & 43.6 & 33.0 \\
\hline \multicolumn{2}{|c|}{ Trade balance $2 /$} & -7.7 & -7.0 & -9.7 & -9.4 & -10.7 & -10.3 & -6.9 & -9.8 \\
\hline \multicolumn{2}{|c|}{$\begin{array}{l}\text { Net capital stock at } \\
\text { end of period } 83 \text { / }\end{array}$} & \multicolumn{5}{|c|}{$\begin{array}{l}\text { Percent of bank assets in } \\
\text { default at end of period: }\end{array}$} & \multicolumn{3}{|c|}{$\begin{array}{l}\text { Percent of deposits } \\
\text { seized by regulators: }\end{array}$} \\
\hline & & & Period & 4 & 6 & 8 & 4 & 6 & 8 \\
\hline Sector 1 & 84.5 & & Bank 1 & 0.0 & 19.0 & 0.7 & 0.0 & 11.9 & 0.0 \\
\hline Sector 2 & 87.0 & & Bank 2 & 0.0 & 35.9 & 4.7 & 0.0 & 27.9 & 0.0 \\
\hline Sector 3 & 83.2 & & Bank 3 & 0.0 & 29.8 & 1.1 & 0.0 & 21.8 & 0.0 \\
\hline Sector 4 & 71.7 & & Bank 4 & 0.0 & 66.1 & 0.6 & 0.0 & 58.1 & 0.0 \\
\hline Sector 5 & 85.4 & & Bank 5 & 0.0 & 15.3 & 0.6 & 0.0 & 7.3 & 0.0 \\
\hline
\end{tabular}

1/ All indices are normalized with respect to the base simulation.

2/ As a percentage of GDP.

3/ Capital stocks are normalized to levels of the benchmark case of Table 3.

It is often claimed that banks in developing countries do not following optimizing behavior for noneconomic reasons. In particular, they are under political pressure to continue lending to insolvent borrowers. Suppose that this is the case here, and banks are not permitted to carry out the optimizing behavior that lead to the outcomes of Table 5 .

\footnotetext{
${ }^{18}$ Recall that banks ration credit with a one period lag after borrowers begin to default. Hence there are no changes in periods 5 and 6 when the defaults occur.
} 
The Central Bank, alarmed by the growing failures in the banking system, decides to carry out an activist monetary policy. Accordingly, it will compensate private banks for any withdrawals of deposits by advancing discount loans equal to the amount of the withdrawal. Alternatively, the Central Bank could carry out open market purchases of government debt from the banking system. Such a policy would, of course, require that banks be endowed with government debt. These loans or open market operations take place with a lag of one period. The aim of such a policy would be to simultaneously reduce interest rates, and to deter a bank run since the increase in cash liabilities of the banks will reduce the share of nonperforming assets out of their total assets. Thus consumers will decrease their withdrawal of deposits from the banking system, which looks less risky than before.

We should make an important caveat. A policy which has the central bank rescuing private banks by compensating monetary policy clearly has risks of moral hazard, after its initial implementation. If the commercial banks were to anticipate such a rescue by the central bank, then they might change their lending behavior and become less risk averse. In our model, this would be equivalent to lowering the value of $\delta_{k}$ for each bank. Introducing moral hazard would significantly complicate our model, since it would require elements of uncertainty that we have not incorporated. We thus will suppose that any government policies used to counteract the effects of shocks are completely unanticipated. Hence they do not change the behavior of banks, borrowers, or depositors. ${ }^{19}$ The resulting outcomes of this unanticipated central bank monetary compensation are given in Table 6 .

We observe some interesting changes, compared with Table 4 where activist monetary policy was not employed, and where there was no optimizing bank behavior. In particular, there is a significant decline in the interest rate after the imposition of expansionary monetization. The resulting lower real interest rate brings about a uniform increase in final period capital, and real GDP rises by period 8 . The budget deficit declines, as a percentage of GDP, since debt service has been reduced. On the other hand, the expansion in credit, combined with fixed exchange rates, has caused there to be an increase in the trade deficit.

This suggests that the use of an activist monetary policy may offer a route to alleviating the problems of nonperforming bank assets, even when banks do not optimize. On the other hand, the increase in the trade deficit, as well as the higher rate of inflation, compared with Table 5, raise questions as to the sustainability of this policy. In addition, we still have the problem of bank failures in periods 5 and 6 . Suppose we now implement an additional government policy.

${ }^{19}$ An interesting avenue of research would be to derive some welfare measure of the cost of moral hazard in this case. That is, what are the costs of saving banks in terms of increased inefficient lending. Since, however, we do not permit the possibility of changed borrower and bank behavior, in the face of government bailouts, we cannot investigate this issue. 
Table 6. A Monetary Contraction with Compensating Central Bank Behavior

\begin{tabular}{|c|c|c|c|c|c|c|c|c|c|}
\hline \multicolumn{2}{|l|}{ Period } & 1 & 2 & 3 & 4 & 5 & 6 & 7 & 8 \\
\hline \multicolumn{2}{|c|}{ Nominal GDP 1/ } & 100.0 & 110.3 & 137.8 & 160.5 & 175.7 & 199.7 & 148.0 & 222.2 \\
\hline \multicolumn{2}{|c|}{ Real GDP 1/ } & 100.0 & 106.1 & 110.6 & 113.0 & 117.8 & 117.1 & 116.3 & 118.0 \\
\hline \multicolumn{2}{|c|}{ Price Level } & 100.0 & 104.0 & 124.6 & 142.0 & 149.1 & 170.6 & 127.3 & 188.3 \\
\hline \multicolumn{2}{|c|}{ Interest Rate } & 1.8 & 3.2 & 7.8 & 10.1 & 17.7 & 43.6 & 54.3 & 28.9 \\
\hline \multicolumn{2}{|c|}{ Budget deficit 2/ } & 5.9 & 5.8 & 10.3 & 9.6 & 12.4 & 12.1 & 42.0 & 30.2 \\
\hline \multicolumn{2}{|c|}{ Trade balance $2 /$} & -7.7 & -7.0 & -9.7 & -9.4 & -10.7 & -10.3 & -7.6 & -10.8 \\
\hline \multicolumn{2}{|c|}{$\begin{array}{l}\text { Net capital stock at } \\
\text { end of period } 83 /\end{array}$} & & \multicolumn{4}{|c|}{$\begin{array}{l}\text { Percent of bank assets in } \\
\text { default at end of period: }\end{array}$} & \multicolumn{3}{|c|}{$\begin{array}{l}\text { Percent of deposits } \\
\text { seized by regulators: }\end{array}$} \\
\hline & & & Period & 4 & 6 & 8 & 4 & 6 & 8 \\
\hline Sector 1 & 96.1 & & Bank 1 & 0.0 & 19.9 & 0.7 & 0.0 & 11.9 & 0.0 \\
\hline Sector 2 & 97.1 & & Bank 2 & 0.0 & 35.9 & 4.6 & 0.0 & 27.9 & 0.0 \\
\hline Sector 3 & 96.3 & & Bank 3 & 0.0 & 29.8 & 1.1 & 0.0 & 21.8 & 0.0 \\
\hline Sector 4 & 89.8 & & Bank 4 & 0.0 & 66.1 & 0.6 & 0.0 & 58.1 & 0.0 \\
\hline Sector 5 & 95.7 & & Bank 5 & 0.0 & 15.3 & 0.6 & 0.0 & 7.3 & 0.0 \\
\hline
\end{tabular}

1/ All indices are normalized with respect to the base simulation.

2/ As a percentage of GDP.

3/ Capital stocks are normalized to levels of the benclumark case of Table 3.

Let us, as a final example, see if combining a reduction in government spending with the expansionary monetary policy can bring further improvement in the banking sector. Presumably the fiscal tightening should reduce pressure on the interest rate. We will therefore reduce public spending by 20 percent. Thus if government spending was previously 20 percent of GDP it would now be 16 percent. We will suppose this fiscal austerity begins at the same time as does the monetary contraction. That is, in period 5, when the initial contraction is imposed, there is a corresponding spending reduction. Thus there should be a corresponding reduction in borrowing requirements, again reducing pressure on the interest rate. The results of this exercise are shown in Table 7.

If we observe the results of this simulation, compared with those of Table 6, where only monetary compensation was used, we see a number of improvements. As might be expected, the budget deficit declines, as does the nominal interest rate in all but one of the four periods after the austerity has been imposed. At the same time, final net capital rises in all but one sector and there are is only one sectoral bankruptcy, in sector 2. As in the base case, sector 2 is small so no bank in the final four periods defaults. It would therefore appear that combining tight fiscal policy with expansionary monetary policy offers the best solution to a shock to the banking system. 
Table 7. Monetary Contraction with Monetary Compensation and Fiscal Reduction

\begin{tabular}{|c|c|c|c|c|c|c|c|c|c|}
\hline \multicolumn{2}{|l|}{ Period } & 1 & 2 & 3 & 4 & 5 & 6 & 7 & 8 \\
\hline \multicolumn{2}{|c|}{ Nominal GDP $1 /$} & 100.0 & 110.3 & 137.8 & 160.5 & 158.4 & 176.7 & 208.0 & 266.7 \\
\hline \multicolumn{2}{|c|}{ Real GDP 1/ } & 100.0 & 106.1 & 110.6 & 113.0 & 112.7 & 111.9 & 117.6 & 117.1 \\
\hline \multicolumn{2}{|c|}{ Price Level } & 100.0 & 104.0 & 124.6 & 142.0 & 140.5 & 157.9 & 176.8 & 227.7 \\
\hline \multicolumn{2}{|c|}{ Interest Rate } & 1.8 & 3.2 & 7.8 & 10.1 & 16.8 & 47.9 & 23.2 & 13.6 \\
\hline \multicolumn{2}{|c|}{ Budget deficit 2/ } & 5.9 & 5.8 & 10.3 & 9.6 & 9.5 & 9.1 & 23.4 & 18.3 \\
\hline \multicolumn{2}{|c|}{ Trade balance $2 /$} & -7.7 & -7.0 & -9.7 & -9.4 & -10.9 & -10.2 & -11.6 & -12.4 \\
\hline \multicolumn{2}{|c|}{$\begin{array}{l}\text { Net capital stock at } \\
\text { end of period } 83 /\end{array}$} & \multicolumn{5}{|c|}{$\begin{array}{l}\text { Percent of bank assets in } \\
\text { default at end of period: }\end{array}$} & \multicolumn{3}{|c|}{$\begin{array}{l}\text { Percent of deposits } \\
\text { seized by regulators: }\end{array}$} \\
\hline & & & Period & 4 & 6 & $\overline{8}$ & 4 & 6 & 8 \\
\hline Sector 1 & 92.5 & & Bank 1 & 0.0 & 1.0 & 0.8 & 0.0 & 0.0 & 0.0 \\
\hline Sector 2 & 99.3 & & Bank 2 & 0.0 & 5.6 & 4.6 & 0.0 & 0.0 & 0.0 \\
\hline Sector 3 & 100.7 & & Bank 3 & 0.0 & 1.3 & 1.1 & 0.0 & 0.0 & 0.0 \\
\hline Sector 4 & 99.7 & & Bank 4 & 0.0 & 0.7 & 0.6 & 0.0 & 0.0 & 0.0 \\
\hline Sector 5 & 100.6 & & Bank 5 & 0.0 & 0.6 & 0.5 & 0.0 & 0.0 & 0.0 \\
\hline
\end{tabular}

1/ All indices are nonnalized with respect to the base simulation.

2/ As a percentage of GDP.

3/ Capital stocks are normalized to levels of the benchmark case of Table 3.

This conclusion holds for other types of shocks. In the Appendix we carry out a similar set of simulations for a trade shock. The conclusions are the same. Optimizing private banks can recover from defaults by rationing credit, although with a lag and after initial failures. Compensating monetary policy has similar effects, in the absence of optimizing bank behavior, although at the cost of higher inflation and a deterioration in the trade balance. Compensating monetary policy, combined with fiscal tightening at the time of the shock, seems to offer the best policy mix.

\section{Conclusion}

We have constructed a dynamic general equilibrium model that incorporates financial assets and a banking sector. The model can be used to address a variety of issues, but we focus on responses to endogenously created bank failures and possible policy responses. As initial examples, we have first simulated the model, using stylized parameters derived from several South Asian countries, most of which have significant problems with bank insolvencies. The resulting equilibrium path represents a benchmark case. 
We assume that firms cannot service their debt if the present value of the return to their investments falls below the present value of their debt obligations. A bank panic occurs when the public withdraws deposits, in reaction to worries about defaulting bank assets, leading to higher interest rates and more enterprise failures. We consider two types of shocks as examples of events that might cause bank failures. The first is an unanticipated monetary contraction. The second is a terms of trade shock.

In both cases the shock causes failures in the banking system, if we assume that banks passively grant loans to all prospective borrowers--behavior that is normally the rule in many developing countries. When banks do optimize by rationing credit to risky borrowers, failures are reduced, but at the cost of declines in real income. We then impose an active monetary policy that compensates banks for withdrawn deposits. The outcome indicates that the policy can significantly relieve pressure upon the banking system, even in the absence of optimizing bank behavior, but at the cost of higher inflation and current account deterioration.

Our final simulation improves upon the sole use of compensating monetary policy. Here we impose a reduction in spending in order to tighten fiscal policy and thereby reduce budgetary pressure. The resulting decline in interest rates eliminates all investor defaults, and hence nonperforming assets of the banking system. We conclude that the combination of compensating monetary policy and restrictive fiscal policy may offer the best way of responding to a bank crisis, if private banks are not able or willing to ration credit to risky borrowers. 


\section{A Terms of Trade Shock}

Let us suppose that there is a shock to the country's terms of trade, beginning in period 5. As an arbitrary example, we will suppose that the import price index decreases by $30,37.5,20$ and 25 percent in the last four years of the simulation. Corresponding to Table 3 , Table Al gives the result of this simulation, assuming that banks do not ration credit to risky borrowers, that is, nonoptimizing behavior.

Table A1. A Terms of Trade Shock

\begin{tabular}{|c|c|c|c|c|c|c|c|c|c|}
\hline \multicolumn{2}{|l|}{ Period } & 1 & 2 & 3 & 4 & 5 & 6 & 7 & 8 \\
\hline \multicolumn{2}{|c|}{ Nominal GDP $1 /$} & 100.0 & 110.3 & 137.8 & 160.5 & 171.2 & 182.6 & 130.6 & 144.3 \\
\hline \multicolumn{2}{|c|}{ Real GDP 1/ } & 100.0 & 106.1 & 110.6 & 113.0 & 116.8 & 113.1 & 116.9 & 108.8 \\
\hline \multicolumn{2}{|c|}{ Price Level } & 100.0 & 104.0 & 124.6 & 142.0 & 146.6 & 161.4 & 117.2 & 137.2 \\
\hline \multicolumn{2}{|c|}{ Interest Rate } & 1.8 & 3.2 & 7.8 & 10.1 & 6.8 & 6.6 & 22.9 & 27.6 \\
\hline \multicolumn{2}{|c|}{ Budget deficit $2 /$} & 5.9 & 5.8 & 10.3 & 9.6 & 12.8 & 12.7 & 17.7 & 17.0 \\
\hline \multicolumn{2}{|c|}{ Trade balance $2 /$} & -7.7 & -7.0 & -9.7 & -9.4 & -10.5 & -15.3 & -14.7 & -16.9 \\
\hline \multicolumn{2}{|c|}{$\begin{array}{l}\text { Net capital stock at } \\
\text { end of period } 83 /\end{array}$} & \multicolumn{5}{|c|}{$\begin{array}{l}\text { Percent of bank assets in } \\
\text { default at end of period: }\end{array}$} & \multicolumn{3}{|c|}{$\begin{array}{l}\text { Percent of deposits } \\
\text { seized by regulators: }\end{array}$} \\
\hline & & & Period & 4 & 6 & $\overline{8}$ & 4 & 6 & $\overline{8}$ \\
\hline Sector 1 & 97.2 & & Bank 1 & 0.0 & 17.7 & 17.9 & 0.0 & 9.7 & 9.9 \\
\hline Sector 2 & 95.0 & & Bank 2 & 0.0 & 31.8 & 32.6 & 0.0 & 23.8 & 24.5 \\
\hline Sector 3 & 95.2 & & Bank 3 & 0.0 & 27.0 & 28.2 & 0.0 & 19.0 & 20.2 \\
\hline Sector 4 & 89.1 & & Bank 4 & 0.0 & 63.6 & 64.0 & 0.0 & 55.0 & 56.0 \\
\hline Sector 4 & 96.0 & & Bank 5 & 0.0 & 13.4 & 14.0 & 0.0 & 5.4 & 6.0 \\
\hline
\end{tabular}

1/ All indices are normalized for this base simulation.

2/ As a percentage of GDP.

3/ Capital stocks are normalized to levels of the benchmark case of Table 3.

As might be expected, the terms of trade shock has caused there to be a decline in real income and a deterioration in the trade balance. The budget deficit has increased, leading to corresponding increases in the real interest rate. As a result, firms 2 and 4 are unable to service their debts, and the banks have part of their deposits seized by regulators. The outcomes of this simulation are thus similar to those of Table 4, when there was an unexpected monetary contraction. 
The effects of optimizing bank behavior, compensating monetary policy, and fiscal austerity, are similar to those in the case of the monetary contraction. We will report only the results of fiscal austerity, combined with compensating monetary policy, in Table A2.

Table A2. A Terms of Trade Shock with Monetary Compensation and Fiscal Reduction

\begin{tabular}{|c|c|c|c|c|c|c|c|c|c|}
\hline \multicolumn{2}{|l|}{ Period } & 1 & 2 & 3 & 4 & 5 & 6 & 7 & 8 \\
\hline \multicolumn{2}{|c|}{ Nominal GDP 1/ } & 100.0 & 110.3 & 137.8 & 160.5 & 149.3 & 162.3 & 140.1 & 148.1 \\
\hline \multicolumn{2}{|c|}{ Real GDP 1/ } & 100.0 & 106.1 & 110.6 & 113.0 & 109.5 & 107.5 & 107.2 & 106.4 \\
\hline \multicolumn{2}{|c|}{ Price Level } & 100.0 & 104.0 & 124.6 & 142.0 & 136.4 & 151.0 & 130.7 & 139.2 \\
\hline \multicolumn{2}{|c|}{ Interest Rate } & 1.8 & 3.2 & 7.8 & 10.1 & 6.9 & 8.2 & 3.6 & 1.5 \\
\hline \multicolumn{2}{|c|}{ Budget deficit $2 /$} & 5.9 & 5.8 & 10.3 & 9.6 & 7.6 & 8.9 & 6.6 & 16.9 \\
\hline \multicolumn{2}{|c|}{ Trade balance $2 /$} & -7.7 & -7.0 & -9.7 & -9.4 & -11.0 & -16.3 & -16.9 & -17.4 \\
\hline \multicolumn{2}{|c|}{$\begin{array}{l}\text { Net capital stock at } \\
\text { end of period } 83 /\end{array}$} & \multicolumn{5}{|c|}{$\begin{array}{l}\text { Percent of bank assets in } \\
\text { default at end of period: }\end{array}$} & \multicolumn{3}{|c|}{$\begin{array}{l}\text { Percent of deposits } \\
\text { seized by regulators: }\end{array}$} \\
\hline & & & Period & 4 & 6 & 8 & 4 & 6 & 8 \\
\hline Sector 1 & 102.1 & & Bank 1 & 0.0 & 0.6 & 0.0 & 0.0 & 0.5 & 0.0 \\
\hline Sector 2 & 97.0 & & Bank 2 & 0.0 & 3.2 & 0.0 & 0.0 & 2.9 & 0.0 \\
\hline Sector 3 & 101.0 & & Bank 3 & 0.0 & 0.7 & 0.0 & 0.0 & 0.7 & 0.0 \\
\hline Sector 4 & 99.2 & & Bank 4 & 0.0 & 0.4 & 0.0 & 0.0 & 0.4 & 0.0 \\
\hline Sector 5 & 103.5 & & Bank 5 & 0.0 & 0.3 & 0.0 & 0.0 & 0.3 & 0.0 \\
\hline
\end{tabular}

1/ All indices are normalized for this base simulation.

2/ As a percentage of GDP.

3/ Capital stocks are normalized to levels of the benchmark case of Table 3.

Our results are similar to those when there was a monetary contraction. We see that fiscal austerity, combined with compensating monetary policy, has left all banks solvent. By the final period there are also no nonperforming assets. As might be expected, the reduction in government spending has caused an initial sharp reduction in real GDP, although by period $8 \mathrm{GDP}$ is near its previous level. The budget deficit and interest rates have been significantly reduced, and there is hence an increase in final period capital stocks. 


\section{BIBLIOGRAPHY}

Altig, D., C. Carlstom, and K. Lansing, 1995, "Computable General Equilibrium Models and Monetary Policy Advice," Journal of Money, Credit, and Banking, Vol. 27, No. 4 (November), pp. 14

Ball, S. and A. Feltenstein, 1998, "Basic Macroeconomic Options for Bangladesh: A Numerical Analysis," Journal of Asian Economics, Vol.9, No. 2, pp. 281-305.

Bandiera, O., G. Caprio, P. Honohan, and F. Schiantarelli, 1999,"Does Financial Reform Raise or Reduce Savings?" unpublished World Bank discussion paper.

Benjamin, N. C. and S. Devarajan, 1985, "Oil revenues and economic policy in Cameroon: Results from a computable general equilibrium model," World Bank Staff Working Paper No. 745 (Washington, DC: The World Bank).

Blejer, M, E. Feldman, and A. Feltenstein, 1998, "Exogenous Shocks, Contagion, and Bank Soundness: A Macroeconomic Framework," unpublished International Monetary Fund discussion paper.

Calormiris, C., and B. Wilson, 1998, "Bank Capital and Portfolio Management: The 1930's Capital Crunch and Scramble to Shed Risk," NBER Working Paper No. W6649, July.

Chari, V., V., L. Christiano, and M. Eichenbaum (1995), "Inside Money, Outside Money, and Short-Term Interest Rates," Journal of Money, Credit, and Banking, Vol. 27, No. 4, (November).

de Melo, J., 1988, "Computable general equilibrium models for trade policy analysis: A Survey," Journal of Policy Modeling.

Diaz-Gimenez, J., E. Prescott, T. Fitzgerald, and F. Alvarez, 1992, "Banking in Computable General Equilibrium Economies," Journal of Economic Dynamics and Control, 16, No. $3 / 4$, pp. 533-60.

Feltenstein, A., and S. Morris, 1990, "Fiscal Stabilization and Exchange Rate Instability: A Theoretical Approach and Some Policy Conclusions using Mexican Data," Journal of Public Economics, August, 42, pp. 329-356.

Feltenstein, A. (1992), "Oil Prices and Rural Migration: The Dutch Disease Goes South," Journal of International Money and Finance, No. 11, pp. 273-291.

Feltenstein, A. and A. Shah, 1993, "General equilibrium effects of taxation on investment in a developing country: The case of Pakistan," Public Finance 48 No. 3: 366-86 
Grais, W., J de Melo, and S. Urata, 1986, "A general equilibrium estimation of the effects of reductions in tariffs and quantitative restrictions in Turkey in 1978," in General Equilibrium Theory, Project Evaluation and Economic Development: Essays in Honour of Sir W. Arthur Lewis, (London: George Allen and Unwin).

Hossain, M. Zahid, Abdur Rab, and K. Mustahidur Rahman, 1995, "Developing a Policy Reforms Evaluation System in Bangladesh," paper presented at the Commencement Workshop on Project on Policy Reforms in Bangladesh.

Kehoe, T. and J. Serra-Puche, 1980, "A Computational General Equilibrium Model with Endogenous Unemployment: An Analysis of the 1980 Fiscal Reform in Mexico, Journal of Public Economics, October, 22(1), pp. 1-26.

Kydland, F., and E. Prescott, 1977), "Rules Rather than Discretion: The Inconsistency of Optimal Plans," Journal of Political Economy, Vol. 85, No. 3, June 1977, pp. 473-91.

Kouwennar, A., 1988, A Basic Needs Policy Model: A General Equilibrium Analysis with Special Reference to Ecuador, Amsterdam: North-Holland.

Labadie, P., 1995, "Financial Intermediation and Monetary Policy in a General Equilibrium Banking Model," Journal of Money, Credit, and Banking, Vol. 27, No. 4 (November), pp. 1290-1315.

Levy, S., 1987, "A Short Run General Equilibrium Model for a Small, Open Economy," Journal of Development Economics, 25, No. 1: 63-88

Lewis, J.D. and S. Urata, 1984, "Anatomy of Balance of Payments Crisis: Application of a Computable General Equilibrium Model to Turkey, 1978-1980," Economic Modelling 1, No. 3: 281-303.

Merton, R., 1995, "Financial Innovation and the Management and Regulation of Financial Institutions," Journal of Banking and Finance, 19: pp. 461-82.

Narayana, N. S. S., K. S. Parikh, and T. N. Srinivasan, 1991, Agriculture, Growth and Redistribution of Income: Policy Analysis with General Equilibrium Model of India, (Amsterdam: North-Holland; New-Delhi: Allied Publishers).

Shoven, J.B. and J. Whalley, 1984, "Applied General Equilibrium Models of Taxation and International Trade,” Journal of Economic Literature, 22, No 3: 1007-51.

Strotz, R., 1956, "Myopia and Inconsistency in Dynamic Utility Maximization," Review of Economic Studies, Vol. 23 (3), No. 62, pp.165-80. 
Taylor, L., ed., 1990, Socially Relevant Policy Analysis for the Developing World: Structuralist Computable General Equilibrium Models for the Developing World, (Cambridge: MIT Press). 